\title{
GALEN, DIVINATION AND THE STATUS OF MEDICINE ${ }^{1}$
}

Galen's stories about his successes in predicting the development of an illness belong to the best-known anecdotes drawn from his writings. Brilliant pieces of self-presentation, they set Galen apart from his peers, who tried to cover up their ignorance by levelling accusations of magic and divination against their superior colleague. ${ }^{2}$ These accusations are usually interpreted as very real threats, as Roman law punished illicit magic and divination. ${ }^{3}$ Pointing out that Galen sometimes likes to present himself as a mantis and a prophet, others have suggested that the accusations against Galen and his own selfpresentation indicate that the border line between medicine and religion was still fluid. ${ }^{4}$ Both approaches correctly draw attention to the social reality that the accusations betray: they suggest that Galen belongs to a group of healers of dubious standing that populated the empire and thus show that medicine had not a monopoly on healing. Yet such a socio-historical approach may not be sufficient. For one, both explanations have their limitations. Regarding the former, it can be said that Augustus' prohibition of divination aimed at controlling prediction about the emperor and one can doubt that a wide-spread clamp-down of all forms of divination ever was intended. ${ }^{5} \mathrm{~A}$ possible objection to the second view is that throughout his oeuvre Galen emphasises his medicine as a rational undertaking, even as a science (episteme). ${ }^{6}$ If one takes his self-presentation as a mantis to be more than metaphorical and to indicate the not yet fully crystallised identity of medicine as a separate scientific discipline, then Galen's usual way of understanding his own craft as a 'science' is in need of explanation. Besides such possible objections, a different set of questions still needs to be asked: why were precisely accusations of practicising magic and divination levelled against Galen and why do they recur so frequently in his writings? Why divination and not, say, poisoning?

This different type of question will help us to reconsider the relationship between divination and medicine in Galen's oeuvre, a relationship that was close, even in Galen's eyes - and maybe too close for

\footnotetext{
${ }^{1}$ I wish to thank John Wilkins for luring me into dealing with Galen, the audience in Exeter for questions and remarks, and the anonymous reviewer for very useful comments.

${ }^{2}$ Praen. 3.7 p. 84.6-10, 3.17 p. 88.1-7, 10.15-19 p. 124.16-29 Nutton; Hipp. Prog. 3.7 p. 337.14, 3.42 p. 369.9 Heeg; CP 3.18 Hankinson; Loc. Aff. 5.8 361.12-366.5 Kühn; Diff. Feb. 2.7 p. 354 Kühn; Opt. Med. 1.5 p. 285.17-8 BoudonMillot. References to the works and editions of Galen follow the conventions set out in R.J. Hankinson (ed.), The Cambridge Companion to Galen (Cambridge, 2008), 391-403.

${ }^{3}$ V. Nutton, Galen. On Prognosis. Edition, Translation, and Commentary. CMG V 81 (Berlin, 1979), 150; R.J. Hankinson, 'Prédiction, prophétie, pronostic: la gnoséologie de l'avenir dans la divination et la médecine antique' in R. Kany-Turpin (ed.), Signes et prédiction dans l'antiquité (Saint-Etienne, 2005), 147-162, 158.

${ }^{4} \mathrm{~V}$. Boudon, 'Aux marges de la médecine rationnelle: médecins et charlatans à Rome au temps de Galien (Ile s. de notre ère)', REG 116 (2000), 109-31, 131; see also V. Boudon, 'Galien et le sacré', BAGB (1988), 327-37, 335.

${ }^{5}$ See the advice given by Firm. Mat., Math. 2.30.3-4, and the discussion by R. MacMullen, Enemies of the Roman Order: Treason, Unrest, and Alienation in the Empire (Cambridge, Mass., 1966), 131-2; J. North, 'Diviners and divination at Rome' in M. Beard and J. North (edd.), Pagan Priests: Religion and Power in the Ancient World (London, 1990), 49-71; J. Rives, 'Magic in Roman Law: The Reconstruction of a Crime', Classical Antiquity 22 (2003), 313-39, reprinted with an afterword in J. A. North and S. R. F. Price, eds., The Religious History of the Roman Empire: Pagans, Jews, and Christians (Oxford, 2011), 71-108; P. Ripat, 'Expelling Misconceptions: Astrologers at Rome', CPh 106 (2011), 115-54.

${ }^{6}$ E.g. Ars Med. 1 b.1 p. 276.6-7 Boudon. Further references and discussion in V. Boudon, 'Art, science et conjecture chez Galien' in J. Barnes and J. Jouanna (edd.), Galien et la philosophie (Vandoeuvres and Geneva, 2002), 269-98, 277-83.
} 
comfort in the eyes of some modern scholars. Drawing on recent research that has shown that much of Galen's polemic is about marking his discipline off from other competing sets of knowledge, ${ }^{7}$ I shall argue that accusations of divination imply that a doctor oversteps what is perceived to be his proper domain of knowledge and that they thus point to a debate about the status of medicine as a discipline. The accusation may imply a social depreciation, but not necessarily so: as we shall see, Galen recognises divination as a proper art (techne) and even allows it some competence in medical matters. In that case, the sting of the accusation rather lies in the fact that it suggests that Galen (or another doctor) goes beyond the realm of knowledge which is his own and in which he can claim competence. None of this obviously means that for Galen medicine would not be the supreme art when it comes to healing, but thinking that one's own craft is the best, does not necessarily imply that the other art is worthless or irrational. Rather, for Galen, medicine and divination are two parallel arts

This will lead us, in a second part, to a discussion of the relationship between religion and medicine in Galen. If, as I shall argue, Galen does not depreciate divination as an irrational religious phenomenon, as often has been thought, then this raises the question how he thought about religion in general. Whereas most attention so far has been dedicated to reconstructing Galen's personal beliefs, ${ }^{8}$ I wish to focus on the conceptualisation of the relationship between religion and medicine implicit in his oeuvre. The traditional view relies on what I would call the 'purification' or 'disentanglement' model: from Hippocrates onwards medicine is seen as disentangling itself from magic and religion so as to establish itself as a purely rational discipline. ${ }^{9}$ The process obviously was never completed in Antiquity, as Galen's belief in the efficacy of dreams and his acceptance of divination illustrates. ${ }^{10}$ This is a perfectly valid model from a modern perspective, but it relies on implicit assumptions that may distort our understanding of how Galen himself saw the relationship between medicine and religion. Indeed, the model identifies the opposition between medicine and religion as the contrast between rationality and irrationality. The progress of medicine is hence understood as medicine establishing itself as the only true (because rational) source of healing in depreciation of other, irrational, forms of healing. ${ }^{11}$ I will

\footnotetext{
${ }^{7}$ R. Flemming, 'Galen's imperial order of knowledge' in J. König and T. Whitmarsh (edd.), Ordering Knowledge in the Roman Empire (Cambridge, 2007), 241-76; C. Gill, T. Whitmarsh and J. Wilkins (edd.), Galen and the World of Knowledge (Cambridge, 2009).

${ }^{8}$ G. Strohmaier, 'Galen als Vertreter der Gebildetenreligion seiner Zeit', in E.C. Welskopf (ed.), Neue Beiträge zur Geschichte der alten Welt (Berlin, 1965), II, 375-79; F. Kudlien, 'Galen's religious beliefs', in V. Nutton (ed.), Galen: Problems and Prospects (London, 1981), 117-30; H. Schlange-Schöningen, Die römische Gesellschaft bei Galen (Berlin, 2003), 224-35; M. Frede, 'Galen's Theology' in J. Barnes and J. Jouanna (edd.), Galien et la philosophie (Vandoeuvres and Geneva, 2002), 73-126.

${ }^{9}$ L. Edelstein, 'Greek medicine in its relation to religion and medicine', Bulletin of the Institute of the History of Medicine 5 (1937), 201-46; J. Longrigg, Greek Rational Medicine: Philosophy and Medicine from Alcmaeon to the Alexandrians (London, 1993), 1-5; V. Nutton, 'God, Galen, and the Depaganization of Ancient Medicine,' in P. Biller and J. Ziegler (edd.), Religion and Medicine in the Middle Ages (York, 2001), 17-32, 19 (implicitly); Boudon, 'Aux marges' (note 4). See the nuances (for the Hippocratic Period), of J. Jouanna, Hippocrate (Paris, 1992), 279. V. Nutton, Ancient Medicine (London, 2004), 293 rightly stresses the complexity of the relationship between religion and medicine.

${ }^{10}$ Kudlien, 'Religious Beliefs' (note 8). See also Nutton, Ancient Medicine (note 9), 279.

${ }^{11}$ For a critique of traditional models and the various possible constellations of the relationship between medicine and religion, see D.W. Amundsen, Medicine, Society, and Faith in the Ancient and Medieval Worlds (Baltimore and London, 1996), 2-4.
} 
suggest that we cannot project this opposition onto Galen and that we should understand his view of religion in the light of the contemporary discourse on ancient wisdom, which identified a philosophical, truthful core in traditional religion. As such, one could say, we witness in his oeuvre the rationalisation of religion. By this I mean that religion comes to be seen as containing philosophical or scientific knowledge.

\section{GALEN ON DIVINATION}

In the best discussion of Galen's attitude towards divination, R.J. Hankinson has shown that Galen accepts divination as an art (techne), with its own rules and possible efficacy, but as a realm separate from medicine. Indeed, in his treatise On prognosis he lists divination (mantike) among the arts just after reporting that he was accused of being a magician (goes) and shortly before he in the same treatise reports the accusation of being a diviner (mantis): 'They do not see the particular beauty of each study and they cannot stand intellectuals. Geometry and arithmetic they need only in calculating expenses and improving their mansions, astronomy and divination only in forecasting whose money they are going to

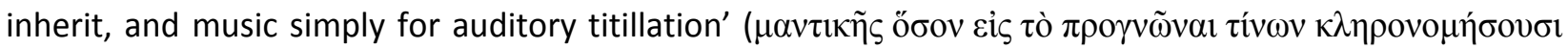
$\chi \rho \eta \sigma o v \sigma v){ }^{12}$ The acknowledgment of the status of techne for divination is an interesting one and not self-evident: the possibility of predicting the future had been disputed, at least since Cicero's treatise on the subject ${ }^{13}$ and the debate was still going on in Galen's day. ${ }^{14}$ Justifications of divination as an art usually argue that it is a stochastic art: it possesses a body of knowledge and rules, but it has to proceed by conjecture given the complexity of its subject matter. ${ }^{15}$ This is, for example, the argument of Quintus in Cicero's De divinatione, where medicine is cited as a parallel art that also relies on conjecture and hence is capable of failure. ${ }^{16}$ As Véronique Boudon has shown, Galen defines the art of medicine also as

\footnotetext{
${ }^{12}$ Praen. 1.14 p. 73.30-74.2 Nutton. Tr. Nutton, Galen on prognosis (note 3), 75.

${ }^{13}$ On De divinatione, see M. Beard, 'Cicero and divination: The formation of a Latin discourse', JRS 76 (1986), 33-46; M. Schofield, 'Cicero for and against divination', JRS 76 (1986), 47-65; J. Blänsdorf, "'Augurenlächlen" - Ciceros Kritik an der römischen Mantik' in H. Wissmann (ed.), Zur Erschliessung von Zunkunft in den Religionen (Würzburg, 1991), 45-65; B.A. Krostenko, 'Beyond (dis)belief: Rhetorical form and religious symbol in Cicero's De divinatione,' TAPA 130 (2000), 353-91.

${ }^{14}$ Critique on divination or questions about its possibility can be found in Oenomaus, Fr. 5-6 (cf. J. Hammerstaedt, Die Orakelkritik des Kynikers Oenomaeos (Frankfurt, 1988), 38-40); Diogenes of Oenoanda Fr. 8.III.7 and 32.II.1 Chilton; Alexander of Aphrodisias, De fato 17, 31; Plut., Pyth. Oracl. 25.407C and Vit. Cic. 17.4. Gal., Inst.Log. 17.8 p. 44-45 Kalbfleisch envisages the possibility that mantike does not exist. See S. Iles Johnston, 'Introduction: Divining Divination', in S. I. Johnston and P. Struck (edd.), Mantikê: Studies in Ancient Divination (Leiden, 2005), 1-28 and W. Burkert, 'Signs, commands, and knowledge: Ancient divination between enigma and epiphany', in the same volume, 29-49.

${ }^{15}$ J. Kany-Turpin, 'La divination augurale romaine, une science des signes?' in C. Lévy, B. Besnier, and A. Gigandet, (edd.), Ars et ratio. Science, art et métier dans la philosophie hellénistique et romaine (Coll. Latomus 273) (Brussel 2003), 61-74; W.E. Klingshirn, 'Divination and the disciplines of knowledge according to Augustine' in K. Pollmann and M. Vessey (edd.), Augustine and the disciplines. From Cassiciacum to Confessions (Oxford, 2005), 113-40.

${ }^{16}$ Cic., Div. 1.24: "At non numquam ea, quae praedicta sunt, minus eveniunt." Quae tandem id ars non habet? Earum dico artium, quae coniectura continentur et sunt opinabiles. An medicina ars non putanda est? Quam tamen multa fallunt. See also Cic., Nat.D. 2.12, 3.5; Sext. Emp., Math. 1.72, 2.13; Diog. L. 7.149; Amm. 21.1.14; Serv., ad Aen. 10.75; Mart. Cap. 9.892K. See D. Wardle, Cicero. On Divination. Book 1 (Oxford, 2006), 165; F. Guillaumont, Le De divinatione de Cicéron et les théories antiques de la divination (Brussels, 2006). For a Christian example of
} 
a stochastic art, because it has to apply sound principles, which render it similar to science (episteme), to its object, namely individual bodies that are subject to change. ${ }^{17}$ Especially in the act of prognostication, medicine shows itself to be a stochastic art. ${ }^{18}$ Galen thus represents the interesting case not of a defender of divination who uses the example of the esteemed discipline of medicine to claim respectability for divination, but a doctor who explicitly accepts that divination functions in the same way as medicine does and that both are arts. As we shall see immediately, Galen even uses divination to explain the functioning of medicine.

In order to understand the full implications of this, it is useful to take a closer look at a key passage and the way it has been interpreted by R.J. Hankinson in a fundamental paper. Indeed, throughout his article, he seems to wish to shield Galen from accusations of engaging in irrational practice. Whilst he concedes that Galen as a second-century Roman is bound to believe in gods and divination, Hankinson emphasises that Galen's practice as a doctor is rational. The last sentence of his paper is revelatory: 'Tout cela [the seemingly miraculous treatment and healing of Eudemus as told in On prognosis] n'a rien à faire avec la divination et tout à faire avec la médicine rationelle, philosophique, scientifique'. ${ }^{19} \mathrm{He}$ is right in so much that Galen indeed sets medicine apart from divination. But because he wishes to demonstrate that Galen is a rational doctor untinged by irrational religion, his account tends to be one-sided and suggests a rejection of divination by Galen. ${ }^{20} \mathrm{~A}$ discussion of an example given by Galen himself in his commentary on the Hippocratic treatise On regimen in acute diseases will help to make clear that Galen's attitude is different.

Galen explains a remark made by Hippocrates that sometimes doctors disagree among themselves as to the right diet for a patient and that one can compare this to disputes among diviners. After an exposition of how various kinds of diviners can be grouped under the label manteis, Galen comes to the core of the argument: 'those who take part in the divinatory arts differ among themselves no less than do doctors in

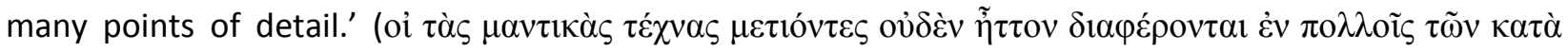

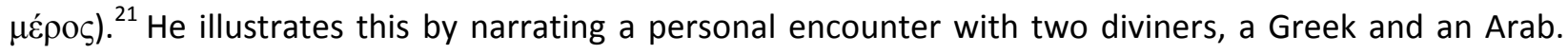
The latter argued that a bird coming from the right indicates a recovery for a woman, and one from the left for a man. The Greek maintained the opposite. Galen asked both if the height on which the bird flies and its distance from the observer plays a role. The Arab denied this, but the Greek, drawing on books by famous bird-watchers, insisted that the bird had to be right in the middle - if not, the sign had an opposite meaning. The story serves Galen to make two points. One is that the Greek had a higher level of technical knowledge (technikoteros, p. 130.4 Helmreich). The other is that both diviners agree on most cases: few birds will come right in the middle, so that usually the Greek and the Arab will make the same

treating medicine and divination as parallel arts, see Augustine, De divinatione daemonum (G. Bardy, J.-A. Beckaert and J. Boutet, Oeuvres de Saint Augustin. 10. Mélanges doctrinaux (Paris, 1952), 647).

${ }^{17}$ Boudon, 'Art, science' (note 6), 289-90. See, e.g., Loc.Aff. 1.1 p. 14.7-12 Kühn. For the difference between Galen's definition of medicine as a stochastic art and that of Alexander of Aphrodisias, see K. lerodiakonou, 'Alexander of Aphrodisias on medicine as a stochastic art' in P.J. van der Eijk, H.F.J Horstmanshoff, and P.H. Schrijvers (edd.), Ancient Medicine in its Socio-Cultural Context (Amsterdam, 1995), 473-85, spec. 481-3.

${ }^{18}$ Hipp. Aph. 1.12 p. 382.7-18 Kühn.

${ }^{19}$ Hankinson, 'Prédiction' (note 3), 161.

${ }^{20}$ Hankinson, 'Prédiction' (note 3), 158: 'rejet de la divination'.

${ }^{21}$ Gal., HVA 1.15 p. 129.13-4 Helmreich. 
prediction. The Greek, however, has additional knowledge which allows him to be more precise. Here Galen reconnects with the overall context of the Hippocratic work he is commenting on. The author of that treatise had noted the disagreement among doctors whether one should give the patient barleywater (ptisane) or not, and in what form and composition. In fact, Galen argues, disagreement among 'artisans', not only diviners but also musicians and orators, is based on the error of identifying partial

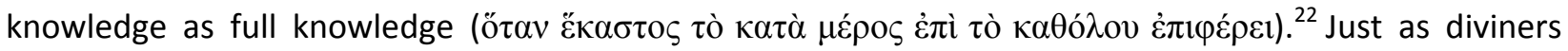
may seem to disagree, doctors may seem to contradict each other because they have failed to think through their art.

The story has been interpreted by Hankinson to imply that divination is no part of Galen's medicine and that it has a questionable status, ${ }^{23}$ whilst Vivian Nutton noted that Galen 'disputes the premisses [of the diviners], not their successes. ${ }^{24}$ This is not what Galen meant. The story can only function on the assumption that divination is an art, with its own correct principles and premisses, which for that reason can yield success. Indeed, Galen explicitly justifies the superior knowledge of the Greek diviner with reference to his reliance on superior theoretical treatises of which he lists a number of authors. ${ }^{25}$ Only on the condition that it is a true art, can divination illuminate something about the nature of medicine, that other art. This may seem uncomfortable to us modern scholars, but it is the logical consequence of Galen's acceptance of the parallelism between divination and medicine. Even more unsettling for our view of Galen may be that the story implies that he recognises the reliability of predictions by diviners: the story clearly assumes that the diviners can say something about the life expectancy of a patient. The fact that divination does possess knowledge does not mean, however, that it is an equally good art in medical matters, nor that the predictions made by a doctor are of the same nature as those by a diviner - 'a ridiculous thought' according to Galen. ${ }^{26}$ Diviners predict apodicticly, saying that a patient will recover on that day, without taking into account, as the doctor does, that recovery is conditional on the nature of the patient and that of the disease. ${ }^{27}$ Nor does it imply that divination is part of medicine: medicine and divination may be parallel arts, but that should not lead to a blurring of the boundaries. ${ }^{28}$ Galen's desire to set both apart can even result in the polemical claim that he has never seen a prophet make a correct prediction in Rome. ${ }^{29}$ The reason why Hankinson reads the passage from the Commentary on Acute diseases as he does, is that he implicitly projects the opposition rational/irrational

\footnotetext{
${ }^{22}$ Gal., HVA 1.15 p. 131.31 Helmreich.

${ }^{23}$ Hankinson, 'Prédiction' (note 3), 1556: 'statut douteux de la divination'.

${ }^{24}$ Nutton, On Prognosis (note 3), 170. H. von Staden, 'Galen's daimon: reflections on "irrational" and "rational",' in N. Palmieri (ed.), Rationnel et irrationnel dans la médecine ancienne et médiévale: aspects historiques, scientifiques et culturels (Saint-Étienne, 2003), 15-43, 26 sees it as an example of Galen's contradictory attitudes.

${ }^{25}$ Gal., HVA 1.15 p. $130.31-2$ Helmreich.

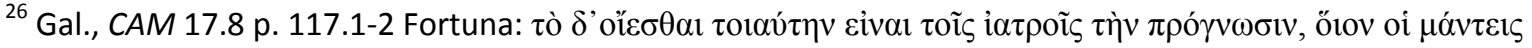

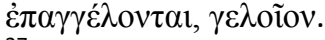

${ }^{27}$ Gal., CAM 17.8-13 p. 117.1-118.3. Cf. Gal., Di. Dec. 1.12 p. 833.6-12 Kühn; Hipp. Epid. II.comm. III p. 282.10-3 Wenkebach. Galen's critique echoes a general critique on divination, namely that it does not enquire into the causes (cf. Cic., Div. 2.17-8, 1.16). But that does not disqualify it as an art.

${ }^{28}$ Gal., Praen. 3.7 p. 84.5-10 Nutton; Hipp. Epid. VII comm IV 27 p. 244.5-23 Wenkebach. See the comments by V. Nutton, Galen. On My Own Opinions. Edition, Translation, and Commentary. CMG V 3, 2 (Berlin, 1999), 136-7.

${ }^{29}$ Gal. Hipp. Epid. I comm III 17 p. 125.25-7 Wenkebach. For the activity of diviners in healing, see the discussion by S.I. Johnston, Ancient Greek Divination (Malden, MA and Oxford, 2008), 119-25.
} 
onto the parallelism that Galen sees between medicine and divination. In such a perspective, in order to present Galen as a rational doctor, he must be seen as rejecting divination as irrational. In fact, for Galen, divination is as 'rational' as medicine (in that it relies on principles and knowledge), but not as accurate and powerful in matters of health. Moreover, his acceptance of divination as an art, even in relation to medical matters, does not indicate that the boundaries between both arts were blurred in his mind: on the contrary, divination has its own principles and handbooks, just as medicine. Precisely this allows him to set both clearly apart, and argue, obviously given his own position as a doctor, for the superiority of medicine.

With this in mind, we can turn to our main source for Galen's views on medical prediction. Galen's treatise on prognosis is, in Simon Swain's words, 'one of the most exciting texts' written in the Second Sophistic. ${ }^{30}$ Rather than a theoretical treatise it is 'unadulterated self-advertisement ${ }^{31}$ in truly Second Sophistic mode. It contains a series of case studies that prove Galen's great ability in predicting the development and outcome of diseases. The cause célèbre is Galen's treatment of the Peripatetic philosopher Eudemus, whose illness and recovery Galen accurately predicted against the advice of other doctors who had abandoned him. It is a true success-story: not only did Galen succeed against the expectations of the patient and other doctors, Eudemus was also a well-connected man. Suddenly Galen was the star of the elite, much to the chagrin of other leading doctors, such as Antigenes and Martianus,

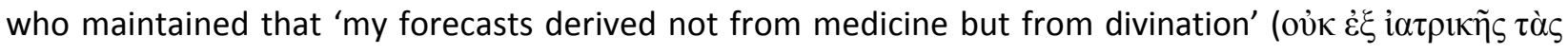

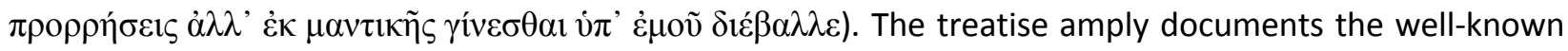
accusations of Galen being a goes or a mantis. ${ }^{32}$

I wish to start by drawing attention to the preface of the work, which is very instructive for the themes under discussion. It is, in fact, a treatise that is explicitly about the status of medicine. ${ }^{33}$ From its first sentence, the essence of medicine is defined by its ability to predict: 'How impossible it is, Epigenes, for the majority of doctors to foretell what is going to happen to their patients in each illness' (ő $\sigma o v \mu \varepsilon \dot{\varepsilon} v \dot{\varepsilon} \pi \mathrm{i}$

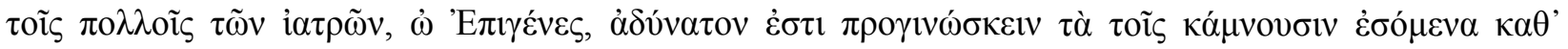
$\dot{\varepsilon} \kappa \alpha ́ \sigma \tau \eta \nu$ vó $\sigma o v) .{ }^{34}$ In the current cultural decline, Galen laments, semblance of ability is now more valued than true knowledge. 'Whenever a doctor has been properly trained, predicts the occurrence in a patient of a delirium, rigor, depression, haemorrhages, abscesses to the ears or elsewhere, vomiting, sweating, a stomach upset, a fainting fit, or anything of the kind, he appears a strange monstrosity to the laity because of his rarity. The predicter is so far from gaining their respect that he would think himself lucky if

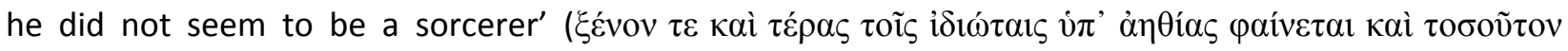

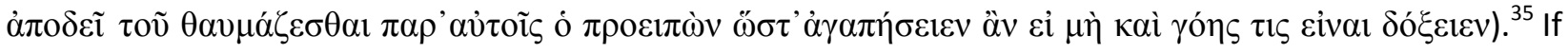
the ignorance of the plebs could be excusable, the attitude of the other doctors is worse. The predictor

\footnotetext{
${ }^{30}$ S. Swain, Hellenism and Empire : Language, Classicism, and Power in the Greek World AD 50-250 (Oxford, 1996), 359.

${ }^{31}$ G.E.R. Lloyd, 'Galen's un-Hippocratic case-histories', in Gill, Whitmarsh and Wilkins (edd.), World of Knowledge (note 7), 115-131, 126.

${ }^{32}$ Gal., Praen. 3.7 p. 84.7-8 Nutton. For further references, see note 2.

${ }^{33}$ The discussion can be seen as inspired or backed up by Plato: the Platonic references that Nutton On prognosis (note 3), 147 inventorises, are about the status of rhetoric: cf. Gorgias 502E, 517A, Rep. 491A-494D.

${ }^{34}$ Gal., Praen. 1.1 p. 68.3-4 Nutton. Tr. Nutton, On prognosis (note 3), 69.

${ }^{35}$ Gal., Praen. 1.6 p. 70.6-7 Nutton. Tr. Nutton, On prognosis (note 3), 71.
} 
cannot claim that his theory is in fact the one expounded by Hippocrates and thus nothing new, for that would reveal the ignorance of the doctors. Nor can he claim that he invented it, for then he would be lying and increase the suspicions of sorcery. General envy is the result, driving the other doctors either to killing their skilled competitor or forcing him into exile. As a consequence, good doctors, truly skilled, will leave the city and withdraw from society, enjoying a life of peace with the 'best' and the gods.

The preface shows that what is at stake in Galen's competition with other doctors: the possession of true knowledge and the status of medicine. True medical knowledge, Galen shows, is based on tradition. All successful predictions, he suggests, are based on Hippocrates. Therefore a successful doctor does not offer new knowledge, but follows Hippocrates and the Asclepiads. The decline of contemporary medical knowledge is in his eyes caused by a lack of respect for the knowledge of old. As a consequence, trained doctors are not better than ordinary people: they fail to see when something comes about by knowledge and art. In Galen's account the accusation of divination or magic levelled against a skilled doctor betrays an ignorance of what medicine is about: it is the result of ignorance about what the precise realm of knowledge medicine actually occupies. Such lack of knowledge leads to a misunderstanding of the art of medicine and to a confusion of the two parallel arts of medicine and divination. If we look at the accusations from the other side, the same conclusion is reached. The accusation of magic levelled against Galen implies that according to his enemies, his successful predictions overstep what is realistically possible within the limits of medicine. According to them, being so accurate is impossible without recourse to means that go beyond medicine and hence without blurring boundaries that should remain strictly drawn. ${ }^{36}$

Galen's interest in mentioning the accusations is thus identical to that of his enemies in making them: to demonstrate that the other side has failed to respect the boundaries of their discipline, and hence lacks the kind of knowledge that marks out a true doctor. The emphasis in the preface of On Prognosis on the authoritative medical tradition thus well prepares the rest of the treatise, which is basically a long list of exclusively successful predictions: his insertion into a respectable tradition demonstrates why Galen is so successful without overstepping the boundaries of his art. In apparent contrast with this desire to highlight his superior craft without recourse to non-medical means, is the fact that in the treatise Galen clearly enjoys the reputation of being a wonderworker and prophet. ${ }^{37}$ This is maybe less surprising than it seems at first sight: the fact that Galen can make his audience think that he is a diviner only demonstrates even more clearly that his medicine is superior to all in the light of his earlier suggestion that only a lack of knowledge causes one to mistake medicine for divination. In addition, Galen's general attitude towards other disciplines is characterised by what one could call 'intellectual imperialism': to

\footnotetext{
${ }^{36}$ Cf. Gal., Ut.Diss. 10 p. 906.2 Kühn, Syn. Puls. 6 p. 447.5 Kühn, SMT 6 p. 263.10 Kühn. V. Nutton, 'Murder and miracles. Lay attitudes towards medicine in Classical Antiquity,' in R. Porter (ed.), Patients and Practioners. Lay Perceptions of Medicine in Pre-Industrial Society (Cambridge, 1985), 23-53, 46 notes that boundaries were delimited, 'but there was not total annexation.'

${ }^{37}$ Gal., Praen. 7.8 p. 107.32, 8.1 p. 111.13-18, 10.16 p. 124.18-20 Nutton. See also Dig. Puls. 2.1 p. 825 Kühn; Loc. Aff. 5.8 p. 365.10-366.5 Kühn; Cris. 3.8 p. 737.6-738.6 Kühn.
} 
raise his own status as a doctor, he likes to present himself the ultimate philosopher ${ }^{38}$ but also claims a better understanding of the heavens than astronomers and astrologers. ${ }^{39}$

There remains one final question to ask: why could the relationship with divination acquire this key role in determining the status of medicine for Galen? The answer probably lies in Galen's assimilation of the Hippocratic tradition. The Prognostic opens by saying that to cultivate prognosis is the 'most excellent thing' to do for a doctor. This idea remained central in the medical tradition that placed itself in this tradition, and became a key element in defending the status of the discipline. As late as the early seventh century, for example, Stephanus the Philosopher produced a commentary on Hippocrates' Prognostic. Commenting on the preface of the work, he notes: 'For prognosis is more important than both diagnosis and anamnesis, since only God has the power of prognosis. And it is because of this, namely prognosing, that we (doctors) resemble God and are considered godlike; for foreknowledge belongs to a higher, divine power. ${ }^{40}$ Correct prognosis is, crucially, essential for maintaining the status of the art: 'the one who prognoses keeps both himself and the art free from guilt and censure', by curing those who can be cured and not intervening when the prognosis is death. ${ }^{41}$ This basic Hippocratic tenet is further made explicit by parallels with other arts. This is so much more necessary given the fact that medicine has not reached the status of the art of geometry, which is infallible: dealing with unstable matter, a doctor can err. Correct prognosis thus helps to limit errors by showing that in certain cases no treatment can help anymore, so that medicine does not get the blame for when the patient dies. ${ }^{42}$ It is interesting to note that even in this late period, medicine is still set in parallel with other arts, in particular divination. Stephanus' foremost concern is with the status of medicine: wrong prognosis, especially in cases that end in the death of the patient, dangerously impacts on the standing of the doctor and his art. In contradistinction with the methodists, who thought that prediction is the job of a prophet and not of a doctor, ${ }^{43}$ Galen also saw prognostication as the key activity for a doctor and, with characteristic modesty, could suggest to have perfected that art. ${ }^{44}$ In such a view of medicine, one understands well both Galen's interest in mentioning accusations of divination and his tendency to enjoy the reputation of being a prophet or diviner. They demonstrate that he has perfected the art of prognosis and hence is the ultimate doctor.

\section{GALEN AND ANCIENT WISDOM}

\footnotetext{
${ }^{38}$ This is the purpose of Opt.Med. On the debates between medicine and philosophy in this period, see L. Van Hoof, Plutarch's Practical Ethics. The Social Dynamics of Philosophy (Oxford, 2010), 211-54.

${ }^{39}$ G.J. Toomer,' Galen on the Astronomers and Astrologers', Archive for history of exact sciences 32 (1985), 193-

206; G.W. Cooper, 'Galen and astrology: A match made in heaven?' Early Science and Medicine 16 (2011), 110-46.

${ }^{40}$ Stephanus, Comm. Progn. pr p. 30. 24-6. Tr. J.M. Duffy, Stephanus the Philosopher. A Commentary on the Prognosticon of Hippocrates (Berlin, 1983), 31.

${ }^{41}$ Stephanus, Comm. Progn. 1.1.1 p. 36.7-19. Tr. Duffy, Stephanus (note 40), 37. See L. Edelstein, Ancient Medicine, (Baltimore, 1967), 65-85.

${ }^{42}$ Stephanus, Comm. Progn. 1.13 p. 50.4-16.

${ }^{43}$ Gal., Hipp. Progn. 1.1 p. 197.12 Heeg; Nat. Fac. 1.12 p. 29.7 Kühn.

${ }^{44}$ Gal., Adv. Typ. Scr. 2 p. 479.16-480.2 Kühn; CAM 17 p. 112.13-26 Fortuna; Opt. Med. Cogn. 1.2-6 p. 49-50 Iskandar; Opt. Med. Cogn. 4.5 p. 65.6-18 Iskandar; Loc. Aff. 3.4 p. 145-7 Kühn; Dig. Insomn. p. 833.10 Kühn. As noted by Lloyd, 'Case-histories' (note 31), 124-5, Galen only focuses in Prognosis on succesful outcomes, in clear contrast with Hippocratic treatises on prognosis. See Nutton, Ancient Medicine (note 9), 237-9; D. Lehoux, What did the Romans know? An Inquiry into Science and Worldmaking (Chicago, 2012), 112-14 on prognosis in Galen.
} 
It has been observed that the issue at stake in the debate staged by Cicero in On divination was not whether divination existed as such: rather, the question was to determine if it was a merely human art in which the gods had a part or not. ${ }^{45}$ Galen's acceptance of divination as an art parallel to medicine therefore does not in itself imply that he viewed it as a religious practice: indeed, the anecdote about the Greek and Arab diviner does not refer to their religious systems but to their knowledge, as put down in handbooks. There are, however, some indications that Galen did attribute a religious aspect to divination: in particular the repeated polemical association of divination and sorcery suggests that the supernatural was seen as entering into it. The acceptance of divine involvement would also fit well with the often noted fact that Galen accepts the reality of many religious phenomena, such as inspirational dreams. ${ }^{46}$ Such an openness to religious phenomena is usually explained with reference to the age Galen lived in. That is undoubtedly correct, but in this final section I would like to propose a more specific context in which we can understand this. We can detect in Galen traces of a specific conception of religion that was very common in his age, especially among Stoics and Platonists - a view that G. BoysStones has labelled 'ancient wisdom'. ${ }^{47}$

My starting point is the fragmentary Commentary on the Hippocratic Oath, attested in Arabic sources. Franz Rosenthal has divided the fragments in three sets: on the origin of medicine; on Asclepius; and on Hippocrates. The authenticity of the work is disputed: ${ }^{48}$ Rosenthal suggests its authenticity but ultimately leaves the question open; the treatise does not figure, in turn, in the list of Hankinson's Companion to Galen. V. Nutton, however, considers it authentic. ${ }^{49}$ The uncertainty is caused by the absence of other testimonies and by the late and indirect transmission, as they are drawn from an Arab treatise that reports and sometimes cites Galen. Only a new study of the Arab text can demonstrate whether Rosenthal's identification of Galenic fragments is indeed correct and, as this is beyond my competence, I accept his analysis of the text. I wish to challenge, however, one important argument against the authenticity of the fragments, namely the seemingly incongruous contents: the middle section is an allegorical interpretation of the cult, myth, and statue of Asclepius, unique in Galen's oeuvre. I shall argue, first, that the fragments contain nothing incongruous when set in the context of similar texts of that time and, second, that they provide some explanations for positions on religious matters taken by Galen elsewhere in his undoubtedly authentic works. If we can indeed link the Commentary on the Hippocratic Oath with other works of Galen, we have an additional argument for its authenticity and for the fact that the views attributed to Galen in the Arab text are indeed his.

The first question addressed by Galen seems to have been the origin of medicine. He defends an inspirational and divine origin of the craft. 'Some say that God gave (the craft of medicine) to mankind

\footnotetext{
${ }^{45}$ Lehoux, What did the Romans know? (note 44), 37.

${ }^{46}$ See the works referred to in note 8 and 9 and S.M. Oberhelman, 'Galen, On diagnosis from dreams', Journal for the History of Medicine 38 (1983), 36-47.

${ }^{47}$ G.R. Boys-Stones, Post-Hellenistic Philosophy. A Study of its Development from the Stoics to Origen (Oxford, 2001). The implications of this for religion are developed in P. Van Nuffelen, Rethinking the Gods. Philosophical Readings of Religion in the Post-Hellenistic Period (Cambridge, 2011).

${ }^{48}$ M. Meyerhof, 'Autobiographische Bruchstücke Galens aus arabischen Quellen', Sudhoffs Archiv für Geschichte der Medizin 22 (1929), 72-86, 73.

${ }^{49} \mathrm{~V}$. Nutton,'The patient's choice : a new treatise by Galen' CQ 40 (1990), 236-57, 254; 'Galen's library' in Gill, Whitmarsh and Wilkins (edd.), World of Knowledge (note 7), 19-34, 26; Ancient Medicine (note 9), 279.
} 
through inspiration. The representatives of this theory follow the opinions of Galen, Hippocrates, all the Theorists, and the Greek poets. Others say that man invented it (himself). They are the Empiricists, Methodists, Thessalus the Sophist, and Philinus. ${ }^{50}$ The statement is supported by the fact that such an exalted science cannot be invented by the intellect of $\mathrm{man}^{\prime 51}$ and the existence of divine healing through dreams - the fragment refers to Serapis and Asclepius in Epidaurus, Cos, and Pergamon 'the lastmentioned one being my own city. ${ }^{52}$ The divine origin of medicine is clearly part of Galen's defence of the status of medicine as he practises it: he is able to cite Hippocrates and the Greek poets to his defence and thus anchor his view firmly in authoritative Greek tradition, and, moreover, attribute a divine origin to his craft. The fact that medicine has an inspirational origin and that cures can still be revealed in dreams, should not be interpreted to indicate that it is not a rational art. Rather, as Galen makes clear, divine dreams do not offer cures that go beyond what a doctor can prescribe and do. They do not transcend the science of medicine, for the knowledge of the gods is quantitatively but not qualitatively different. ${ }^{53}$ On that model, the commentary on the Hippocratic Oath suggests that Asclepius revealed medicine as a body of rational knowledge to mankind. That we are to understand Galen in this way, will become clear below.

The middle section, offering an allegorical interpretation of the cult, statue and myth of Asclepius, is too long to be discussed entirely here. The allegory is carefully targeted to justify his own kind of medicine and to defend the status of the art. Galen points, for example, to the 'egg' that statues of Asclepius hold in the hand, ${ }^{54}$ symbolising the earth and the universe, and indicating 'that the whole world needs medicine'. The relationship with divination is also highlighted. 'Galen says: [Asclepius] is said to be the son of Apollo, because physicians must possess some of the ability of the diviner, for it is not unnecessary for a good physician to have some knowledge of the things that might happen later on. ${ }^{, 55}$ Later on, the presence of the snake is explained as a sign that, just as this sharp-sighted animal that never sleeps, a doctor must be able to look into the future and warn his patients in time. ${ }^{56}$ Then the laurel wreath is explained as follows: 'Or it is because the (laurel) wreath is common to the craft of

\footnotetext{
${ }^{50}$ F. Rosenthal, 'An Ancient Commentary on the Hippocratic Oath', Bulletin of the History of Medicine 30 (1956), 52$87,56$.

${ }^{51}$ Rosenthal, 'Commentary' (note 50), 59.

${ }^{52}$ Rosenthal, 'Commentary' (note 50), 60. The reference to 'my own city' suggests that Galen is indeed reporting his own views, and not those of someone else.

${ }^{53}$ Kudlien, 'religious beliefs' (note 8), 118; Schlange-Schönigen, Welt (note 8), 228-30. Cf. Gal., UP 2 p. 92.3 Helmreich = p. 812-3 Kühn; Cur. Rat. Ven. Sect. 23 p. 314-5 Kühn; MM 3.7 p. 207.1-5 Kühn. The principle is also clearly enunciated by Artem., Onir. 4.22. See also Prop. Plac. 2 p. 58.4-7 Nutton: Sed quod ipse sunt, scio per operationes earum quoniam ab ipsis est regimen animalium et inveniuntur in divinationibus et in somniis. On dreams in medicine, see S.M. Oberhelman, 'Dreams in Graeco-Roman medicine', ANRW II.37.1 (1993), 121-56; H. Versnel, Coping with the Gods. Wayward Readings in Greek Theology (Leiden, 2011), 406, 416.

${ }^{54}$ It is unclear what the egg refers to. Pausanias describes a statue in Sicyon which holds a pine cone (2.10.3). Many statues had an omphalos at their feet. A misinterpretation of any of these objects may lie at the basis of Galen's assertion, or the text may preserve an unknown tradition. See E.J. and L. Edelstein, Asclepius. A Collection and Interpretation of the Testimonia (Baltimore, 1945), Vol. 2, 226; J. Schouten, The Rod and the Serpent of Asklepios (Amsterdam, London and New York, 1967); G. Strohmeier, 'Asklepios und das Ei', Festschrift Franz Altheim (Berlin, 1970), 143-53, 448-54.

${ }^{55}$ Rosenthal, 'Commentary' (note 50), 66-7.

${ }^{56}$ Rosenthal, 'Commentary' (note 50), 70.
} 
medicine as well as divination, and people, therefore, were of the opinion that the wreath used for physicians and diviners should be one and the same (kind of) wreath. ${ }^{57}$ The allegory concludes on the statement that the chair on which Asclepius sits represents 'the power through which health is gained', again making clear that medicine is the supreme art. $^{58}$ It is interesting to note that throughout this allegory divination and medicine are put into parallel, reminding us of how Galen's views set out in the first section of this article.

It has seemed curious that the 'rational' Galen would engage in such complex allegories, leading to the rejections of the authenticity of the treatise noted above. Yet, when set in the context of contemporary views about the relationship between philosophy and religion, and in particular ideas about ancient wisdom, this strangeness disappears. Building on suggestions of M. Frede, ${ }^{59} \mathrm{G}$. Boys-Stones has argued that Post-Hellenistic philosophy is characterised by a new conception of authority, justified by the theory of ancient wisdom. ${ }^{60}$ The theory, which Boys-Stones traces back to Posidonius, holds that in the Golden Age, the earliest generations of mankind possessed pure, philosophical knowledge of the world. When moral decline caused the Golden Age to come to a close and ideal life in accordance with nature became impossible, the wise ancients invented culture to help organise human life. That culture was based on their perfect insights. They, for example, composed written laws based on the unwritten ones and created religion as a system that translated the metaphysical knowledge into symbols. Given the moral decline of mankind, however, the presence of philosophical knowledge in culture has become obscured, for example through superstition. Moreover, as we lack the intellectual vigour of the ancients, we tend to disagree on what they precisely meant. Hence the conflicting views generated by the various Hellenistic philosophical schools. Only true philosophers, such as Plato, have succeeded in recovering the ancient wisdom in its purity: their authoritative stance in the history of philosophy is thus not only due to the fact that they have achieved fundamental insights, but also because they have retrieved original knowledge. Practising philosophy thus means recovering an original knowledge rather than discovering something new.

As is clear from this description, philosophers that subscribe to this theory tend to identify philosophical knowledge not just in the philosophical tradition, but also outside it, especially in religion. ${ }^{61}$ Among them, allegorical interpretations of specific cults are common, as they are attempts to discover the original kernel of truth. Probably the best-known example is Plutarch's De Iside et Osiride, which interprets the cult and myth of Isis as an account of the metaphysical structure of the universe - an account that can be found in many cults and religions: 'Therefore, this ancient opinion ( $\delta \xi \alpha)$ has come down from theologians and lawgivers to poets and philosophers, being of unknown origin, but awarded

\footnotetext{
${ }^{57}$ Rosenthal, 'Commentary' (note 50), 71.

${ }^{58}$ Rosenthal, 'Commentary' (note 50), 73.

${ }^{59}$ M. Frede, 'Numenius', ANRW 2.36.2 (1987), 1034-75 and 'Celsus philosophus Platonicus', ANRW 2.36.7 (1994), 5183-213.

${ }^{60}$ Boys-Stones, Post-Hellenistic Philosophy (note 47), with the modifications proposed in P. Van Nuffelen, 'Varro's Divine antiquities: Roman religion as an image of Truth', CPh 105 (2010), 162-88 and L. Van Hoof and P. Van Nuffelen, 'Posidonius, the Golden Age, and Ancient Wisdom: A Note on Seneca, Epistulae morales 90', forthcoming in Latomus.

${ }^{61}$ Van Nuffelen, Rethinking the Gods (note 47), 27-100.
} 
strong and tenacious belief, and spread not in speech alone nor in reports, but also in mystery cults and sacrifices, both of barbarians and Greeks, namely that the universe is not suspended by its own without intellect and reason and guidance, nor that there is one reason that rules and directs it as it were with rudders and curbing reins, but many powers and a mixture of evil and good' ${ }^{62}$ Similar allegorical interpretations can be found in the slightly earlier philosophers Varro, Cornutus, and Chaeremon. ${ }^{63}$ The presence of an allegory of Asclepius in the oeuvre of Galen may thus not only be not incongruous, but also an indication that Galen has applied the theory of ancient wisdom to medicine. The third part of the Commentary on the Hippocratic Oath will provide support for this last contention.

The third section of the treatise offers an account of the early history of medicine: 'The family of Asclepius had in the past been bound by oaths and covenants preventing them from teaching medicine to outsiders. They had restricted (the instruction in it) to their children in the medical schools on the islands of Rhodes and Cnidus and in the city of Cos, and had passed it on orally to their heirs. Eventually, however, Hippocrates feared that the craft might be lost, and he therefore fixed it permanently in writing. ${ }^{64}$ Just as in the history of philosophy, a Platonist philosopher such as Numenius identifies Plato as the authoritative figure who was the last true recipient of ancient wisdom, ${ }^{65}$ Galen depicts a continuous tradition running from Asclepius and the Asclepiads to Hippocrates. Slightly earlier than Plato, ${ }^{66}$ Hippocrates seems to have the same role of authority as Plato has in Numenius.

At the same time, however, the decision to put medical theory down in writing did not have just positive consequences, as becomes clear in a crucial passage from De anatomicis administrationibus (2.1 p. 281-2 Kühn) - a passage that provides an important link between an authentic work of Galen and the Commentary on the Hippocratic Oath. Galen notes there that the 'ancients' (i.e. the Asclepiads) did not write treatises on anatomy, a fact that for him does not prove a lack of interest in the matter. Rather, all teaching happened orally, first within the family. With the progress of time, outsiders were taught to, but only on the condition that they were morally perfect. In a next stage, writing became necessary:

'The art of medicine having thus detached itself from the family of the Asclepiads, and becoming always worse through successive generations, people needed writings that preserved its theory. Before that not only no anatomical treatises were needed, but no such writings.'

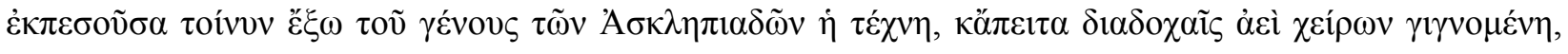

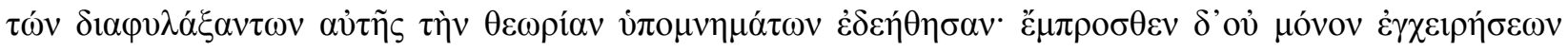

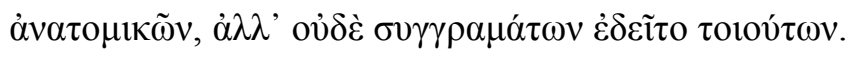

\footnotetext{
${ }^{62}$ Plut., De Is. et Os. 45.369B.

${ }^{63}$ August., De civ. D. 7.5 p. 280 lines 8-21 = Varro, ARD Fr. 225 and August., De civ. D. 7.28 p. 311 lines 7-15 = Varro, ARD Fr. 206; Chaeremon, Frg. 2, 5, 12; Cornutus, Theol. graec. 17 p. 28 I.1 and p. 31 I.12-16, and 35 p. 75 I.18-76 I.5. On these texts, see Van Nuffelen, Rethinking the Gods (note 47), 27-47.

${ }^{64}$ Rosenthal, 'Commentary' (note 50), 80.

${ }^{65}$ Eus., Praep. evang. 9.7.1 = Numenius, Frg. 1 a.

${ }^{66}$ Rosenthal, 'Commentary' (note 50), 78 dates Hippocrates to the reign of Artaxerxes I (465-425 B.C.).
} 
This is a story of moral decline and hence also of a decline of knowledge: ${ }^{67}$ indeed, when medical knowledge is written down, it becomes widely available and invites the uneducated to occupy themselves with it. Hence the pernicious variety of opinions that, according to Galen, characterises his age. This is a feature that we encounter repeatedly in accounts of ancient wisdom: the period since the figure of authority is characterised by a variety of conflicting opinions, due to a moral and intellectual decline. ${ }^{68}$ To stick to the example of Numenius: according to him dissension and deviation from the original truth precisely characterise the history of the Academy after Plato, and in his account this is also connected with the decision of Plato to write Socrates' theories down. ${ }^{69}$ Just as Numenius suggests that only he has succeeded in retrieving Plato's original thoughts, reconnecting with ancient wisdom, and hence transcending the quarrels of the past centuries, Galen argues that only true doctors like himself succeed in restoring some of that original knowledge..$^{70}$

Several features of Galen's view on the history of medicine thus tie in very well with the accounts of the history of philosophy that one finds among philosophers that accept that idea of ancient wisdom: the decline of knowledge since the Asclepiads, only counteracted by a few great minds (including himself); the presence of a perfect body of knowledge at the dawn of humanity; the argument of an authoritative tradition which justifies one's own position; the positive view of religion, in this case the cult of Asclepius which is a symbol system for the art of medicine as it was handed to mankind by the gods. My suggestion is that this shows that Galen borrowed the framework of ancient wisdom from philosophy and applied it to medicine. If this is correct, there are two possible ways to understand this. Explicit statements that can be taken to demonstrate explicitly Galen's adherence to such a view are relatively limited in Galen's oeuvre. One can thus understand their occurrence as evidence of Galen's punctual borrowing of a type of argument that was popular in his age.

It is also possible to attribute a wider significance to these links between Galen and contemporary philosophy. The importance of ancient wisdom that G. Boys-Stones ascribes to Post-Hellenistic philosophy had two important effects on the self-understanding of philosophers. First, they were able to put themselves forward as authoritative interpreters of ancient wisdom or of the texts of a philosopher who had reconnected with ancient wisdom. Precisely in the Post-Hellenistic period authoritative editions of the oeuvre of the great philosophers of the past are being produced. ${ }^{71}$ Second, the widespread eclecticism of Post-Hellenistic philosophy is implicitly justified by the assumption that ultimately all philosophical schools derive from the same ancient wisdom, be it that they have strayed in a greater or

\footnotetext{
67 See Gal. Praen. 10.16 124.19-20 Nutton.

${ }^{68}$ See already the brief comments by Boys-Stones, Post-Hellenistic Philosophy (note 47), 149. The problem of contradiction is made explicit, e.g., in Gal., Lib. Prop 14.1-7 p. 164-5 Boudon-Millot. On Galen's emphasis on moral failure as the cause of intellectual mistakes, see G.E.R. Lloyd, 'Galen on Hellenistics and Hippocrateans.

Contemporary battles and past authorities' in Id., Methods and Problems in Greek Science (Cambridge, 1991), 398416, 400 n. 8 with references.

${ }^{69}$ Eus., Praep. evang. 14.5 = Numenius, Frg. 24; Eus., Praep. evang. 11.10.9-11 = Numenius, Frg. 7: cf. P. Athanassiadi, La lutte pour l'orthodoxie dans le platonisme tardif de Numénius à Damascius (Paris, 2006), 80-90.

${ }^{70}$ Galen repeatedly laments the lack of respect for Hippocrates and the ancients: Praen. 1.8 p. 70.16 Nutton; Opt. Med. Cogn. 2.1 p. 47.15-19, 3.4 p. 52.22 Iskandar; CP 1.1 Hankinson; MM 1 p. 4-6 Kühn. See Nutton, 'Patient's choice' (note 49), 245-6.

${ }^{71}$ In general, see M. Trapp, Philosophy in the Roman Empire (Willston, 2007), 13.
} 
smaller degree from the original kernel of truth. ${ }^{72}$ Both tendencies are prominent in Galen too. As is wellknown, in the words of von Staden, Galen 'tried to recuperate, interpret, corroborate and occasionally correct the thought and meaning of the historical Hippocrates, in part to present himself as a new, less obscure, more accurate, more complete Hippocrates. ${ }^{73}$ At the same time, because Hippocrates presents the transitional stage of medicine from the pure knowledge of the Asclepiads to later written knowledge, Galen can allow himself sometimes to go beyond Hippocrates. Also, given the fact that since Hippocrates medical knowledge is available in written form and that the direct connection with the Asclepiads is gone, interpretation of his doctrines is unchecked. One therefore has to sift through the oeuvre of Hippocrates to determine which works are authentic and which not. ${ }^{74}$ Galen is also obviously eclectic, even if he does not always admit to it. The high status of Hippocrates leads Galen sometimes to ascribing to him concepts that actually derive from, e.g., Aristotle. ${ }^{75}$ Nevertheless, in one way or another, all medical schools ultimately derive their knowledge from that original source and may thus still profess certain good principles. ${ }^{76}$ If there is one thing that needs to be combatted, it is excessive scepticism that rejects the possibility of acquiring true knowledge. ${ }^{77}$ Recently, Galen's eclectic position has been judged sufficiently original to set him apart from his contemporaries: 'This is, I think, the true measure of Galen's originality: he refuses to have anything at all to do with the issues that divide the schools, while still insisting, against the sceptics, that useful knowledge can be won in practical fields, and that it can be based upon more than merely empirical experience. It is this which makes his eclecticism more than that of the average contemporary middle platonist synthesis. ${ }^{.78}$ The features that this quotation highlights the transcendence of school divisions whilst maintaining the belief in knowledge that can be gained - are in fact found among many Post-Hellenistic philosophers, among whom one can also find parallels for

\footnotetext{
${ }^{72}$ Boys-Stones, Post-Hellenistic Philosophy (note 47).

${ }^{73} \mathrm{H}$. von Staden, 'Staging the Past, Staging Oneself: Galen on Hellenistic Exegetical Traditions' in Gill, Whitmarsh and Wilkins (edd.), World of Knowledge (note 7), 132-56, 134. See also R.J. Hankinson, 'Galen's Philosophical Eclecticism', ANRW II.36.5 (1992), 3505-22. Nutton, Ancient Medicine (note 9), 222. As has been noted, the choice for Hippocrates as a figure of authority was less obvious than it now seems in hindsight: Lloyd, 'Galen on Hellenistic' (note 68). There also circulated many different accounts of the history of medicine, clearly deviating from the one offered by Galen: Celsus, De med. Pr; Pliny, NH 29.2.

${ }^{74}$ Lloyd, 'Case-histories' (note 31), 116.

75 J. Jouanna, 'La notion de nature chez Galien', in J. Barnes and J. Jouanna (edd.), Galien et la philosophie. Entretiens sur l'Antiquité classique XLIX (Vandoeuvres and Geneva, 2003), 229-68, noting that Galen depicts Hippocrates as the founder of the doctrine of elementary qualities and Aristotle as the interpreter of views already set out by Hippocrates, even if he is more dependent on Aristotle than Hippocrates. See also P. van der Eijk, P. “"Aristotle! What a thing for you to say!" Galen's engagement with Aristotle and Aristotelians', in Gill, Whitmarsh and Wilkins (edd.), World of Knowledge (note 7), 261-81, 273.

${ }^{76}$ This becomes clear in Galen's attitude towards the Stoics: T. Tieleman, 'Galen and the Stoics, or: The Art of Not Naming', in Gill, Whitmarsh and Wilkins (edd.), World of Knowledge (note 7), 282-99, but also in his acceptance that most medical schools (except for Methodists) have something useful to contribute: Hankinson, 'Eclecticism' (note 73), 3507.

77 D. Béguin, 'Le problème de la connaissance dans le De optima doctrina de Galien' REG 108 (1995), 107-27; R.J. Hankinson, 'Galen on the limitations of knowledge' in Gill, Whitmarsh and Wilkins (edd.), World of Knowledge (note 7), 206-42, 207.

${ }^{78}$ Hankinson, 'Limitations' (note 77), 240. I am not convinced by the argument of M. Vegetti, 'Tradition and truth : forms of philosophical-scientific historiography in Galen's De placitis,' in P. van der Eijk (ed.), Ancient histories of medicine: essays in medical doxography and historiography in classical antiquity (Leiden, 1999), 333-357 that Galen liberates truth from tradition. Tradition is a crucial argument for Galen.
} 
Galen's tendency to polemicise against other schools whilst drawing on their teachings. Without wishing to dispute that Galen's own synthesis is original, the way he goes about forging it and the implicit assumptions it is based upon have strong parallels with what we witness in contemporary philosophy.

In this section, I have argued that Galen understands the history of his discipline in the light of the narrative of ancient wisdom, that is, he accepts that his body of knowledge was already there at the beginning of mankind and that it was later distorted in transmission and thus in need for rediscovery and correct interpretation. As the idea of ancient wisdom implies that this knowledge was also preserved, albeit in allegorical or distorted ways, in traditional religion, the allegory of Asclepius in the Commentary on the Hippocratic Oath now appears less strange within his oeuvre. As the Asclepiads possessed, according to Galen, full knowledge of the art of medicine, it is plausible that he assumed that they had created the image of the founder of their dynasty and had done so in a symbolic fashion, with each attribute saying something about the nature of medicine. As Galen depicts himself as the person who has succeeded in returning to the original insights of Hippocrates, the true heir to the Asclepiads, against the later deviations, it is only natural that he could consider himself also the ideal person to give the correct interpretation of the statue.

\section{CONCLUSIONS}

This paper has focused on the conceptualisation of the relationship between medicine and religion, with divination as a particular case in point, within the oeuvre of Galen. This may seem too limited a perspective for those interested in how medicine really interacted with religion. I hope to have shown, however, that this last question often relies on assumptions that are not those of our sources, in this case Galen. The implicit transfer of a modern paradigm of 'science', which excludes religion as irrational and which rejects tradition in favour of inquiry, ${ }^{79}$ onto Galen has sometimes, as I have argued, obstructed a better understanding of how he thought about divination and religion. It may be better to abandon the category of 'rational' altogether when discussing pre-modern science. ${ }^{80}$ If one thinks this too radical a proposition, then Galen's view of religion is better described as a 'rationalisation' of religion, ${ }^{81}$ in the sense that religion (or parts of it) can be seen as harbouring true philosophical and medical knowledge, albeit not necessarily on the same high level as in technical philosophy and medicine. The openness this implies for religion can be seen in Galen's acceptance of divination as an art (techne) with rules and principles that can be paralleled with those of medicine, but also, in a more direct way, in the allegorical reading of the cult of Asclepius, in which the basic principles of the profession of a doctor and his art are symbolised. The idea that divine healing is practiced according to the same principles as human medicine, backed up by the claim in the Commentary on the Hippocratic Oath that

\footnotetext{
${ }^{79}$ For a famous critique of such a self-understanding of science, see P. Feyerabend, Against Method (London, 1975).

${ }^{80}$ The problem is discussed in and illustrated by H. von Staden, 'Galen's daimon' (note 24), who extensively uses inverted comma's to qualify 'rational'.

${ }^{81}$ On those lines also Schlange-Schönigen, Galen (note 7), 225; von Staden, 'Galen's Daimon' (note 24), 34-38. It often is assumed that from the second century we witness an increased interest in the irrational. The classic argument is that of E.R. Dodds, Pagans and Christians in an Age of Anxiety (Cambridge, 1965). For a critique of Dodds, see R.C. Smith and J. Lounibos (eds.) (1984), Pagan and Christian Anxiety: A Response to E.R. Dodds (Lantham, 1984). I have also argued against this view in Van Nuffelen, Rethinking the Gods (note 47), 233-41.
} 
medical knowledge was of a divine origin, provides additional evidence for such an understanding of religion.

Recently, the impact of religious modes of thinking on Roman epistemology, science, and rhetoric has been highlighted. ${ }^{82}$ In this article, I have been interested in the reverse process, the projection of philosophical knowledge onto traditional religion. Both phenomena need not contradict each other, and indeed should be located at different levels: the former is a matter of deep structures that determine how one conceptualises the world, the latter helps more explicitly to define the role of religion in one's world view. I wish, however, to emphasise that whatever close relationships were established between religion and medicine (and philosophy, for that matter), boundaries were not blurred: it is clear for Galen that divination is not identical to, or a possible substitute for, medicine. Divination can produce true statements about a patient, but it lacks the accuracy and healing power of medicine. Similarly, it is not a bad thing to go to shrines to be healed, but an exclusive reliance on this form of healing may be dangerous. ${ }^{83}$ Only a superstitious man, who has a mistaken view of what the gods do and who they are, will send his doctor away. ${ }^{84}$ Indeed, as philosophers believing in an ancient wisdom repeatedly point out, religion is subject to superstition and change, so there is no certainty that the original knowledge has been well preserved. ${ }^{85}$

Galen's acceptance of divination and medicine as parallel arts goes therefore hand in hand with a clear conscience that both are separate disciplines. The accusations of divination levelled against him, and the occasional gratification he finds in being called a diviner or a magician do not constitute proof that for him (or his accusers) the boundaries were blurred. Rather, in the highly competitive market of the Roman empire, ${ }^{86}$ they indicate that it was a mark of a good doctor to achieve results within the boundaries of his art: doctors accused of divination seemed to rely on other arts and, therefore, to outperform their peers with unacceptable means. In turn, Galen's relish in the accusations can be understood as demonstrating how much his knowledge is elevated above that of his contemporaries: they think he is a charlatan, whereas it is just Hippocrates. Rather than being effective threats that could lead to a trial, such accusations are part of a competition for status within the realm of medicine. Much work has been recently done on Galen's self-presentation, often relying on scholarship on the Second Sophistic. ${ }^{87}$ As I have suggested, the repeated references to the accusations of relying on divination should be seen in that context too: as attempts to highlight his own stellar knowledge. If one accepts my

\footnotetext{
82 Lehoux, What did the Romans know (note 44), 12, 246; M. Beard, 'Cicero's "Responses of the haruspices" and the Voice of the Gods', JRS 102 (2012), forthcoming.

${ }^{83}$ The example is Galen's: Gal. Opt.Med.Cogn. 1.1-2, 1.4 p. 41-43 Iskandar with Nutton, 'Patient's choice' (note 49), 254.

${ }^{84}$ Plut. Superst. $171 \mathrm{AB}, 168 \mathrm{C}$.

${ }^{85}$ On this, see Van Nuffelen, Rethinking the Gods (note 47), 65-71, 217-20.

${ }^{86}$ Nutton, 'Murder' (note 36), 37; V. Nutton, 'Healers in the medical market place: Towards a social history of Graeco-Roman medicine', in A. Wear (ed.), Medicine in Society: Historical Essays (Cambridge, 1992), 15-58.

${ }^{87}$ See most recently W.A. Johnson, Readers and Reading Culture in the High Roman Empire. A Study in Elite Communication (Oxford, 2010), 74-97. See the earlier studies of J. Kollesch, 'Galen und die zweite Sophistik' in V. Nutton (ed.) Galen: Problems and Prospects (London, 1981), 1-11 and H. Von Staden, 'Galen and the Second Sophistic' in R. Sorabji (ed.), Aristotle and After. Bulletin of the Institute of Classical Studies. Supplement LXVIII (London, 1997), 33-54.
} 
argument that Galen borrowed the idea of an ancient wisdom from contemporary philosophy and transferred it to medicine, his account of the history of medicine also helps to position himself as the authoritative exegete who has retrieved Hippocratean and indeed Asclepiad knowledge, thus providing one more argument for his elevated status.

Peter Van Nuffelen, Ghent University, Belgium

peter.vannuffelen@ugent.be 